\title{
Design and Planning of The Porang Supply Chain in South Sumatra
}

Agustina Bidarti a,1,* , Yulius ${ }^{\mathrm{b}, 2}$, Erni Purbiyanti $\mathrm{c}, 3$

a,b,c Department of Agricultural Social-economic, Faculty of Agriculture, Universitas Sriwijaya, Jl. Raya Palembang-Prabumulih KM 32, Indralaya, Ogan lir, South Sumatra.

${ }^{1}$ agustinabidarti@unsri.ac.id; ${ }^{2}$ yulius@fp.unsri.ac.id; ${ }^{3}$ erni.purbiyanti@fp.unsri.ac.id

* Corresponding author

\begin{tabular}{|c|c|}
\hline ARTICLE INFO & ABSTRACT \\
\hline $\begin{array}{l}\text { Article history } \\
\text { Received July 16, 2021 } \\
\text { Revised September 12, } 2021 \\
\text { Accepted October 14, } 2021 \\
\text { Published October 29, } 2021 \\
\\
\text { Keywords } \\
\text { Porang Cultivation } \\
\text { Rural Farming Training Center } \\
\text { Supply Chain Management }\end{array}$ & $\begin{array}{l}\text { The length of the existing porang (Amorphopallus Muelleri B) supply chain is causing a } \\
\text { problem on porang farmers in South Sumatra. The purpose of this research was to } \\
\text { construct a P4S Karya Tani porang supply chain with two evaluation steps. First } \\
\text { beginning, identify the potential demand for porang in South Sumatra from either the } \\
\text { demand and supply perspective. Second, consider the challenges of maximizing market } \\
\text { demand in the porang supply chain in South Sumatra. The research employed a } \\
\text { qualitative descriptive method with a philosophical approach to supply chain } \\
\text { management theory. Based on the discussion, P4S as evaluated the porang supply } \\
\text { chain design, determining that small and large traders must be eliminated as } \\
\text { intermediaries, allowing them to sell porang raw materials direct to consumers and } \\
\text { agro-industry enterprises that export porang. All elements, including that of the local } \\
\text { government, Sriwijaya University, the corporate sector, and banking institutions, should } \\
\text { be involved in the P4S porang supply chain planning. This collaboration is crucial in } \\
\text { order to connect and transform the paradigm of direct sales to consumers, enabling } \\
\text { P4S porang farmers to sell to the nearest consumer, PT PIP in South Lampung, via a } \\
\text { contract farming system. } \\
\text { This is an open access article under the CC-BY-SA license } \\
\text { Copyright } \odot 2021, \text { Bidarti et al }\end{array}$ \\
\hline
\end{tabular}

\section{INTRODUCTION}

Porang (Amorphophallus muelleri B) is the new agricultural commodities export prima donna (Lontoh et al, 2019) Farmers who are members of P4S Karya Tani, South Sumatra, are deeply invested in porang cultivation and management. South Sumatra's P4S Karya Tani must be provided with such an alternative and strategy for constructing a porang supply chain that's also shorter and distinctive from the existing porang supply chain. Porang (Amorphophallus muelleri $B$ ) is now being intensely grown in South Sumatra at the Karya Tani Rural Farming Training Center (P4S) in Tanjung Batu, Ogan llir. Farmers who are members of P4S Karya Tani significantly contribute in the development and improvement of porang cultivation using seeds created by P4S Karya Tani using in tissue culture. This method works well with stem tubers, stem tubers, and leaf tubers or 
bulbil (Wang et al., 2017) The popularity a nd substantial economic value of the porang plant in Indonesia for industrial export cannot be separated from the development of porang cultivation (Yoshida et al., 2020; Lontoh et al., 2019). Porang exports are in high demand due to its high glucomannan content, which is widely employed in the food industry (Zhang et al., 2014), health (Behera \& Ray, 2016), and industrial (Dai et al., 2020; Kashima et al., 2016).

In addition to want a systematic alternative planning, porang farming in P4S Karya Tani must be followed by the construction of effective supply chain management. Porang market demand is quite strong, in line with the growth of porang exports, which is increasing every year. However, domestic cultivation and raw materials did not condemn the increase in porang exports, as the supply of porang was only fulfilled by farmers and small traders. Because of the lack of meticulous planning, delivering supplies from small farmers might be problematic. Small farmers' behaviors, which are based on their income, savings, debt levels, requirements, and spending preferences, often result in sales, supply issues, and injury to farmers in the supply chain management system (Nee, 2008; Sharma et al., 2013; Wu et al., 2016; Berty \& Mulligan, 2016)

Supply chain management in agriculture, according to Bidarti et al. (2019), would include the supply process of suppliers to the company or supplier network, processing in the company or integrated enterprise, distribution and export or distributive network, and distribution and export or distributive network. Because porang farmers are the primary producers, the supply method of suppliers to companies is critical in supply chain management. At this point, supply chain management must cut off as many suppliers as possible, allowing farmers to interact directly with the company all through the bargaining process (Perdana et al., 2020; Handayani et al., 2015; Patil \& Kale, 2016). Farmers, as well as producers, can deal directly with customers and agro-industry firms in this process, maximizing sales volume and ensuring that the market is on target (Amarala et al., 2020; Pradani et al., 2021). Based on the foregoing, study into alternatives to the establishment of the porang supply chain itself from P4S Karya Tani porang farmers is required, particularly in the target market. The purpose of this study, first is design of the porang supply chain formation. Second, getting the development of the porang supply chain at P4S Karya Tani which sided with farmers.

\section{METHOD}

The porang supply chain structure technique was used a qualitative descriptive method similar to Kumar \& Kushwaha (2018). The study was place in Tanjung Batu, Ogan llir Regency, South Sumatra Province, at the Karya Tani Rural Agricultural Training Center (P4S). Because a large-scale porang cultivation is now being created in South Sumatra Province, where the majority of the members are rubber farmers, P4S Karya Tani is utilized as an example to produce a porang supply chain.

This research was part of an effort to help increase regional potential in South Sumatra by increasing the effectiveness and sustainability of the porang supply chain, which is being actively cultivated by P4S Karya Tani farmers and includes porang agro-industry, porang farmers, local government, private sector partners, and academics. In-depth interviews with resource persons, observation, and focus group discussions (FGD) were used to collect data from Tanjung Batu porang farmers, P4S Karya Tani administrators, the local government of Ogan llir Regency and South Sumatra Province, banks, and private parties who were sampled in this study. The questions in this interview are open-ended to provide for more versatility and to allowing for the exploration of new themes or concerns that develop during the interview process.

This study, both descriptively and exploratorily, employs supply chain management theory as a philosophical method in producing supply chain management in building value that is focused on consumer demand. The very first study was conducted in P4S Karya Tani, South Sumatra, as many as 60 member farmers to determine the current situation of porang cultivation and the market chain. The evaluation's findings are also used to shape the construction of the P4S Karya Tani in South Sumatra porang supply chain mapping. The supply chain is being developed in multiple ways, the first of which is identifying the potential need for porang in South Sumatra from both the demand and supply sides. Second, consider the difficulties of completing the P4S Karya Tani South Sumatra porang supply chain in terms of optimizing market demand through porang supply chain management planning. This step also looks at the problems of porang cultivation and supply chain structure at P4S Karya Tani in South Sumatra, such as identifying problems with the P4S Karya Tani supply chain in South Sumatra based on the distribution and profit sharing levels of actors in the porang supply chain system at P4S Karya Tani in South Sumatra with 10 small traders, 3 wholesalers, and 2 exporters as respondents. 


\section{RESULTS AND DISCUSSION}

\section{Map and Design of the Porang Supply Chain in P4S Karya Tani's}

Based on existing theory. There's many several important considerations to take when mapping the porang supply chain in South Sumatra. First, porang supplies are expected to be scarce in 2020 due to a number of interconnected factors. Santoso (2015) observed the growth of porang exports to Japan, Malaysia, Pakistan, and the United Kingdom, which reached in 1991-1997 and then declined from 1998 to 2010. Furthermore, according to Santoso, porang exports have declined due to a lack of domestic cultivation and processed raw materials, rather than a drop in overseas market demand. Porang supplies are in low supply as a result of this situation, particularly in South Sumatra, where porang cultivation at P4S Karya Tani is taking place.

To beginning with, there is a tendency to for supply curve to shift to the left. This is due to the cultivation of porang in South Sumatra, as opposed to East Java, Central Java, West Java, and Lampung, where porang is grown like mushrooms during the wet season. porang plant agriculture in South Sumatra is uneven, with centers only in Musi Banyuasin Regency, Banyuasin Regency and Ogan llir Regency. Porang cultivation, on the other hand, is nearly non-existent in 14 other cities and regencies in South Sumatra. As a result, there is a scarcity of land for porang farming, which must compete with other industrial plant grounds (Yanuriati, et al, 2017; Yanuriati \& Basir, 2020).

Second, there is a proclivity for the supply curve to shift to the right. Porang production in South Sumatra should be in the form of flour or porang chips, however porang nurseries in South Sumatra are primarily in the form of tubers, including stem tubers and frog tubers, due to price control and to generate double demand. This means that farmers that produce porang in order to satisfy their expected seed needs tend to store the crop instead of distributing it to top customers, such as porang agro-industriy companies in the supply chain.

Based on this, the porang supply chain mapping in South Sumatra generally covers the basic pattern:

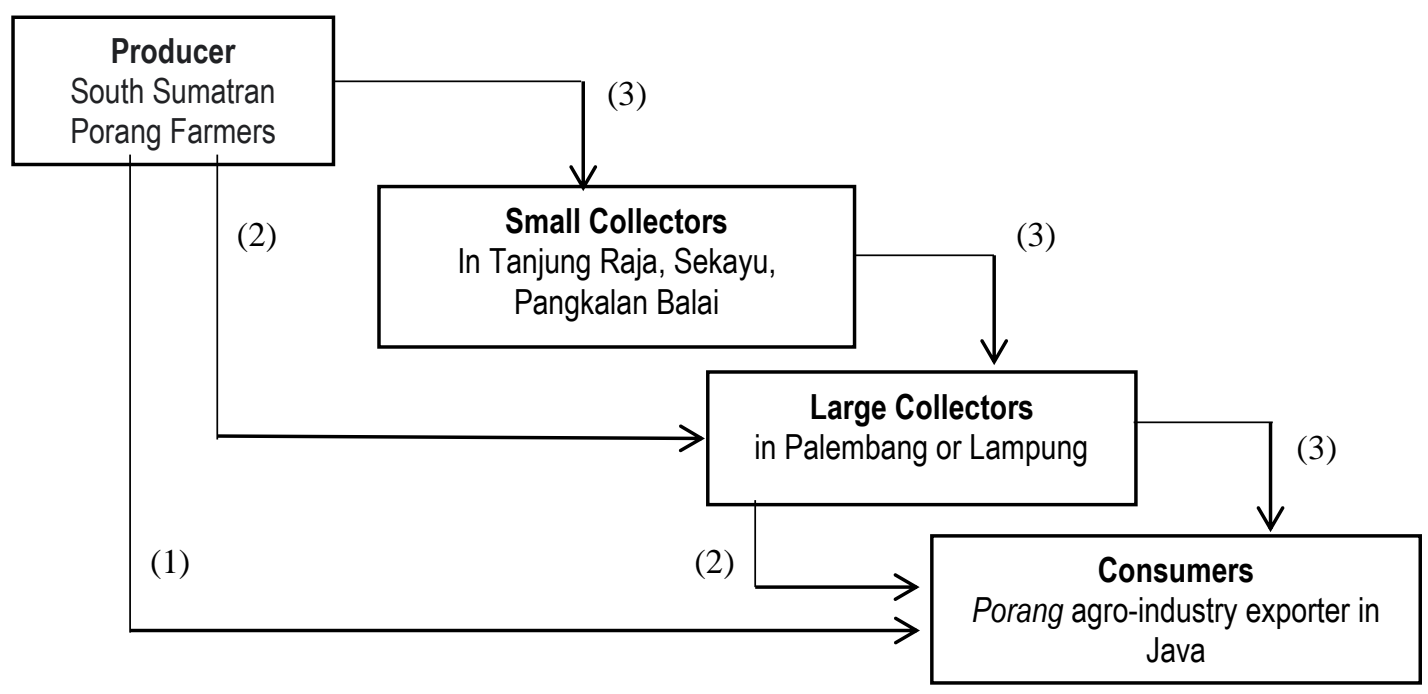

Figure 1: Supply Chain Map at Porang, South Sumatra

Third, porang production costs tend to increase as a result of porang farmers' lack of creativity, as they prefer to acquire seeds directly. Farmers, for example, do not know how to generate seeds using in vitro growing tissue. Fourth, even on the island of Sumatra, the porang market for porang agro-industry companies in South Sumatra is still lacking. PT Ambiko, PT Asia Prima Konjac, CV Agro Alam Raya, PT Algalindo, CV Jia Li in East Java, Star Konjac Nusantara, CV Porang Center Indo, CV Sanindo Putra in West Java, and PT Jagat Raya Indonesia in Jakarta are among the largest porang-exporting agro-industry companies in the world (Yanuriati et al., 2017; Dermoredjo et al., 2021). PT. Mitra Porang Nusantara (MPN) in Pekanbaru, Riau, and PT Paidi Indo Porang (PIP) in South Lampung are the only two agro-industrial companies in Sumatra that export porang. Both of them have only been in operation since 2021.

Farmers as porang producers, small collectors situated in the district capital, and large collectors headquartered in the province capital are the three entities in the porang supply chain in South Sumatra, according to Figure 1 above and in-depth interviews conducted for this study. Farmers as porang producers, particularly in the Musi Banyuasin and Banyuasin areas, and as porang raw material suppliers. Porang 
harvests are marketed in stages in flow 1, with some going to small collectors, major collectors, and even direct customers of porang agro-industry enterprises in Java. Porang producers frequently sell porang straight in the shape of bulbs or frog bulbs in the sales process described above, without separating them first.

Small collectors in the district capital, especially in Ogan llir Regency in Tanjung Raja, Musi Banyuasin Regency in Sekayu or Sungai Lilin, and Banyuasin Regency in Pangkalan Balai or Betung and Sumbawa, are usually individual suppliers, and there are also groups such as porang farmer groups whose activities include selling porang to large collectors in addition to aiding in government programs. The raw materials for porang are usually sorted by small collectors, who separate the good quality items from the damaged ones before selling them to the big collectors. The price of separated porang raw materials varies according to the size and physical shape of the porang.

Large collectors based in Palembang are suppliers who buy porang raw materials from both porang farmers and small collectors in Palembang. All porang raw materials are re-sorted at big collectors to distinguish porang raw materials of acceptable grade from porang raw materials that are not possible. Good-quality raw materials are processed, both in the form of porang chips and porang flour, to ensure that the moisture level of porang and porang glucomannan satisfies the quality standards demanded by porang agro-industrial exporters in Java.

Porang raw features are processed by consumers of porang-exporting agro-industry enterprises not only from major collectors in Palembang, but also through several supply chain entities, as shown in Figure 1: First, flow 1 of the porang supply chain is the flow with the shortest trajectory, in which farmers directly sell porang cultivation goods to consumers, as well as porang agro-industry enterprises in Java. Farmers are usually able to offer porang raw materials in significant quantities and have a cooperative partnership with an agro-industry enterprise that exports porang on the island of Java through a contract system. However, the supply chain flow of porang 1 is very low, barely $3 \%$, according to questionnaires and interviews.

The porang 1 supply chain's flow in South Sumatra, particularly at P4S Karya Tani, needs to be improved. This rise, however, must be accompanied by attempts to build a pattern of cooperation and supply chain shortening by reducing the number of parties in the porang supply chain, crop rotation to engage directly with porang agro-industry companies' consumers. In addition, forming consumers closer to farmers must be followed by cooperation and efforts to cut porang supply chain actors. PT Paidi Indo Porang (PIP) in South Lampung is the porang-exporting agro-industry enterprise nearest to P4S Karya Tani. The contract agreement between porang farmers at P4S Karya Tani and PT Paidi Indo Porang (PIP), a porang-exporting agro-industry enterprise, is more than just a commitment to provide agricultural products. However, as Ncube (2020) and Kangogo et al. (2020) point out, there must be an affirmation of progress and sustainability, especially the company's guidance to farmers to always improve the quality of their porang products. Consequently, eliminating the actors in the porang supply chain reduces the flow of the porang supply chain. Good supply chain management, according to Altman (2015) and Zhang et al. (2021), must be able to cut out as many actors as possible, product quality and farmers to sell their products directly to final consumers at high prices.

Second, the flow of 2 maps of the porang supply chain, namely porang farmers as producers to large collectors in the provincial capital and then to consumers, porang agro-industry exporters on Java. As according Wahyuni et al. (2020), the utilization of porang in the form of porang chips requires the use of washing tools and porang tubers to remove calcium oxalate compounds present in porang, enabling for more special adviser of porang glucomannan. According to Pasaribu et al. (2020), to produce glucomannan flour, the water content must be around 12 and 35 percent, the fineness must be very fine, the color must be shiny white, the sulfite residue must be less than 0.6 , and the glucomannan content must be greater than 80 percent. Farmers still receive insufficient information on the quality of processing and processing technologies for porang, thus farmers sell more porang in the form of tubers than chips or flour. Porang farmers that create P4S Karya Tani should be acquainted with porang processing technologies in order to sell at a better price and sell directly to end users, such as agro-industriy enterprises that export porang. According to the questionnaire and interview flow 2, this porang's supply chain is still modest, at roughly 16 percent.

Third, compared to other trajectories, the flow of the porang supply chain in South Sumatra is the longest, starting with farmers producing porang and passing thru all the small collectors in the district capital, large collectors in the provincial capital, and and at last final consumers, agro-industry companies that export porang in Java. However, the flow of these 3 porang supply chains is long, with 81 percent of them are being finished. As a result, this path must be reduced so that porang farmers do not share too much of their sales with other actors in the porang supply chain, where farmers receive little to no maximum sales. Lin and Wu (2011) propose that in an effective supply chain trajectory, intermediaries for short flows being eliminated, enabling porang farmers to sell raw materials directly to customers at relatively high rates. In order for porang farmers at 
P4S Karya Tani to sell directly to consumers, technology that minimizes the risk of damage to porang tubers in storage as well as high-quality porang processing technology must be accessible.

\section{Porang Supply Chain Management Development Strategy at P4S Karya Tani, South Sumatra}

Porang cultivation and business should therefore be developed in view of potential market opportunities in South Sumatra. There are several more obstacles to the development of the porang supply chain in South Sumatra, including at P4S Karya Tani, as per the supply chain map at the top of this research. The significant effect of intermediaries who enter as actors in the porang supply chain is the main obstacle faced in the structure of the porang supply chain in South Sumatra. Farmers as porang producers must be able to market directly to opportunity to realize, agro-industry enterprises that export porang, by reducing the flow structure of the porang supply chain.

In order to shorten a long supply chain flow, all actors must be involved. The involvement of the local government, both the district government of Ogan llir and the provincial government of Sumatra, is essential since higher education institutions, such as Sriwijaya University, which is a major educational institution and the nearest to P4S Karya Tani, must collaborate. The local government is responsible with persuading investors, the private sector, and especially the banking sector, to participate in supplying capital to porang farmers so that they can cultivate more porang in response to customer needs. Higher education institutions, such as Sriwijaya University, are credited with finding porang organization increase their institutions by teaching them how to grow and process porang crops.

A most essential step in improving the creation of the porang supply chain at P4S Karya Tani in South Sumatra is to improve farmer institutions so that at the initial stage, the supplier network starts at the product ordering stage, initial product processing, transportation of porang products, and warehouses for porang storage. The best solution is to find the closest porang-exporting agro-industry enterprises to P4S Karya Tani. Porang's main consumers in South Sumatra have so far been agro-industry enterprises that distribute porang to Java. The many agro-industry enterprises that export porang in Java, such as PT Ambiko, PT Asia Prima Konjac, Star Konjac Nusantara, CV Porang Center Indo, PT Jagat Raya, and others, all are adding to this predicament. In truth, in South Lampung, there is a porang exporting agro-industry enterprise called PT Paidi Indo Porang (PIP). If the local government should engage porang farmers in P4S Karya Tani in South Sumatra with PT Paidi Indo Porang (PIP), the contract farming system will benefit porang farmers in P4S Karya Tani. According to Kumar \& Kushwaha (2018), developing a supplier model will automatically cut supply chains that are too long, benefiting porang farmers. Direct farmers as porang producers at the local level who can directly relate to porang factory exporters will automatically cut supply chains that are too long.

Moreover, the porang supply chain's contract farming system can reduce the risk of porang cultivation at the farmer level. Contract farming will reduce the risk of porang farmers being not able to sell goods, as well as restrict high sales of porang tubers for P4S Karya Tani farmers. The inclusion of contract farming in the porang supply chain at P4S Karya Tani will help assure the security of porang raw material supply to the exporting industry, resulting in more reliable porang raw material procurement. PT Paidi Indo Porang (PIP) and P4S Karya Tani farmers in South Sumatra can develop a centralized contract farming model in order for this contract farming to be mutually beneficial between the two interests of the processing industry and porang exporters. PT Paidi Indo Porang (PIP), which functions as the buyer of porang raw materials and determines the quality standards of porang products to farmers, conducts contract farming centered on industry and exports. However, PT Paidi Indo Porang (PIP) must have a responsibility to P4S Karya Tani farmers in terms of transforming brand product quality standards.

At times such as these, the Sriwijaya University educational institution can take the services of P4S Karya Tani porang farmers to share their knowledge and talents in processing raw materials to meet the demands of PT Paidi Indo Porang (PIP). As a result of these observations, several things are needed to ensure the effective and efficient flow of the short porang supply chain, as follows. To begin, a community or porang farmer group must be established in P4S Karya Tani. Because the P4S is a non-governmental organization that is managed in groups for agricultural training and education programs, establishing this farmer group is not uncomplicated. (Solihin et al., 2019)

Similarly, the Agricultural Human Resources Extension and Development Agency (BPPSDMP) of the Ministry of Agriculture in Jakarta supports P4S Karya Tani. (Amalia. 2020) Second, in P4S Karya Tani, South Sumatra, there are investors in the porang processing industry who can provide increased added value in porang cultivation and business. These investors are good, including investment aid from local government subsidies, agricultural loans from the Bank of South Sumatra, and programs specifically for porang plants sponsored by Bank Indonesia Representatives in Palembang. 
Hamzah et al. (2020) conducted a competitiveness study to increase exports by studying one of Indonesia's commodities. According to this study, the Trade Specialization Index (ISP) value for Indonesian coffee commodities ranges from 0 to 1 , indicating that Indonesian coffee is already competitive and tends to be an exporting country. Because the Acceleration Ratio (AR) for Indonesian coffee commodities has been positive (more than one). As a result, the value of the Acceleration Ratio, which is always positive, indicates that Indonesia is capable of seizing the international coffee commodity market. From 2008 to 2017, the value of Indonesia's Revealed Comparative Advantages (RCA) was always positive (more than one). A positive RCA value indicates that Indonesian coffee commodities have a comparative advantage over the global average, or that Indonesian coffee commodities are highly competitive in the international market.

However, according to this study, Indonesia's Trade Specialization Index value is between 0 and 1 , indicating that the commodity's competitiveness is still at the export stage if Hiratsuka's product cycle theory is correct. As a consequence, in order to progress, at least two things must be accomplished: To begin, Indonesian coffee commodities must produce on a large scale and begin increasing exports while remaining in the domestic market. Second, the supply of coffee commodities exceeds demand.

P4S Karya Tani should conduct similar investigations into porang supply chain design and planning, particularly in terms of competitiveness. To attract competitiveness in P4S Karya Tani, a large-scale porang product production strategy must be pursued in order to achieve a supply level greater than the demand for porang among P4S Karya Tani porang farmers and agro-industrial companies. According to Relawati et al. (2019), Malang apple agribusiness actors such as farmers, packaging traders, wholesalers, and retailers are already highly integrated. Because the marketing chain is already quite short, this integration is necessary. Only three marketing actors, namely packers, wholesalers, and retailers, bridge the gap between farmers and consumers. In fact, there is no wholesaler's role in determining the price, because the packing trader from Malang Raya determines the selling price to retailers in the consignment system.

Furthermore, in an integrated market, the role of packaging traders is quite dominant. However, it is also stated in this study that, despite being well integrated, it still necessitates three strategy formulations. The three strategies are as follows: increasing Malang apple production and sales; increasing Malang apple promotion; and segmenting the Malang apple market. This study is significant because it is one of the points in the design and planning of the porang supply chain at P4S Karya Tani South Sumatra, particularly in terms of promotion and branding, both through print and electronic media available today. The study of Amarala et al. (2020) found a gap in the use of online social media to reach wider publications, both through the district government website and market places that already exist online.

Maysaroh et al. (2018) conducted a study of a similar supply chain with cassava commodity, and this study found that, while the supply chain management model is standard and good, it consists of farmers, collectors, market traders, and agro-industry parties as chain actors, each of which carries out different activities depending on the inputs they have and the output they produce. Furthermore, the channel is deemed efficient in this study because it has a lower marketing margin value, a higher farmer's share, and a higher profit-to-cost ratio than other channels. However, supply chain development must continue, with the cassava supply chain development mechanism operating in two modes. The first is the supply chain target, with a domestic target market and a development target in the form of technology improvement. Second, the advancement of chain and network management, including efforts to improve coordination and collaboration, as well as the acquisition of formal contractual agreements.

However, further development of this supply chain in its corridor must include cooperation based on verbal contracts between members, a cash transaction system, and government support in the form of capital, equipment, and human resource development training. This research will also help in the design and planning of the porang supply chain at P4S Karya Tani in South Sumatra. The continuous involvement of all parties, including the government, private sector, and universities, is required to maintain the cooperative transaction system between farmers and porang agroindustry, particularly in terms of capital, training, and resource development of porang farmers at P4S Karya Tani.

Furthermore, by involving all parties, this development has many economic and social benefits. Economically, the presence of porang cultivation in P4S with careful design and planning in the supply chain will encourage increasing sustainable porang production (sustainability), which is quite promising, in addition to having abundant land and human resources in porang farming in Ogan llir Regency so that profits can be made in improving the welfare of farmers, particularly porang farmers, through the supply chain. Second, from a social standpoint, the existence of porang cultivation with such design and planning will be usually lauded in Ogan llir Regency in particular and South Sumatra Province in general. A good porang supply chain 
management agricultural program will serve as a model for other commodities in other districts in South Sumatra and Indonesia.

Furthermore, for the Independent Agricultural and Rural Training Center (P4S) Karya Tani, Ogan llir Regency, the porang farming program with a sustainable supply chain in Ogan llir Regency, it is hoped that this collaborative effort will expand more broadly to various regions of South Sumatra and Indonesia, raising the name of the Ogan llir Regency Government in the national arena. Porang cultivation has a lot of potential, and there are a lot of market needs that can't be met completely, so it can be widely marketed to other areas of the Ogan Ilir Regency with a very large area coverage. Furthermore, the Independent Agricultural and Rural Training Center (P4S) Karya Tani, Ogan llir Regency can benefit by gaining experience in serving porang consumers as a downstream porang for export. It can then be used to indirectly increase the production of porang agricultural products while also increasing the income and welfare of farmers in Ogan llir Regency and South Sumatra Province.

The efficiency of transportation costs and the efficiency of processing costs related to the processing of porang tubers that can be done at P4S Karya Tani are both important considerations in the design and planning of the porang supply chain at P4S Karya Tani. The study of Baroh et al. (2021) found that focusing on transportation costs reduced the efficiency of porang prices to the agro-industry of exporting companies. The first step in determining the price efficiency of transportation costs is to calculate the total purchase price of porang as well as transportation costs to the location of the exporter's agro-industry company. Essentially, and theoretically, in supply chain management, the transportation marketing function is typically carried out by marketing agencies, i.e. middlemen.

Of course, in accordance with the study of lqbal et al. (2020), by cutting channels to middlemen and large collectors. As a result, because middlemen and other collectors are being eliminated in the design and planning of this supply chain, consumers, namely the porang exporting agro-industry companies, bear transportation costs. The efficient measurement of transportation costs can be seen if the average cost incurred is still less than the price difference. Meanwhile, for price efficiency based on processing costs, the sum of the purchase price of the coffee and the processing costs that must be less than the selling price of porang is price efficiency based on processing costs (Santoso, 2015; lqbal et al., 2020)

Furthermore, the difference between the selling price and the purchase price of porang, which must be greater than the processing cost, can be analyzed. Loading and unloading, sorting, drying, separating porang tubers, roasting, and packaging costs can be charged to P4S Karya Tani farmers. Based on this, raising according to Yanuriati et al. (2020) the price at the agro-industry level of porang exporters in Lampung.

\section{CONCLUSION}

According to the findings of the study, the porang supply chain in South Sumatra has a relatively long flow. Porang farmers selling directly to final consumers, as well as agro-industry enterprises exporting porang in Java, account for only $3 \%$ of the total. Meanwhile, flow 2 in the porang supply chain in South Sumatra is still low, at around 16 percent, with farmers as porang producers selling to wholesalers in the province capital. Flow 3 of the porang supply chain in South Sumatra, with a tiered structure of porang farmers selling to small traders in the district capital, then wholesalers, and finally consumers. Agro-industry enterprises that export porang in Java account for around 81 percent of the total. This requirement is to design the structure of the porang supply chain in P4S Karya Tani, South Sumatra, by removing small and large traders as intermediaries. P4S Karya Tani porang farmers would be able to sell porang raw materials directly to consumers and porang-exporting agro-industry enterprises.

Furthermore, all elements, including district governments, provincial governments, Sriwijaya University, and private and banking institutions, such as Bank Sumselbabel and Bank Indonesia Representative in Palembang, must be involved in developing the porang supply chain structure at P4S Karya Tani while minimizing problems in the supply chain structure. The role of the local government in linking and transforming the sales-toconsumer paradigm, which has previously been dominated by agro-industry enterprises exporting porang in Java, is essential. Additionally, a pattern like this in the porang supply chain in South Sumatra can not only improve the existing porang supply chain structure, but also increase and popularize porang crop cultivation and processing in all other cities and regencies, ensuring that the motto of South Sumatra as a national food barn is properly realized. 


\section{ACKNOWLEDGMENTS}

The publication of this article was funded by DIPA of Public Service Agency of Universitas Sriwijaya 2021. SP DIPA-023.17.2.677515/2021, on November 23, 2020. In accordance with the Rector's Decree Number: 0007/UN9/SK.LP2M.PT/2021, on April 27, 2021.

\section{REFERENCES}

Altman, M. (2015). Cooperative Organizations as an Engine of Equitable Rural Economic Development. Journal of Co-Operative Organization and Management, 3(1): 14-23.

Amarala, A. N. G., Supardi, S., \& Harisudin, M. (2020). Strategi Pemasaran Produk "Tempe Samodra" Kelurahan Mojosongo, Kecamatan Jebres, Kota Surakarta. Agriecobis: Journal of Agricultural Socioeconomics and Business, 3(1), 08-16.

Amalia, A. (2020). Peran Pusat Pelatihan Pertanian dan Pedesaan Swadaya dan Hubungannya dengan Perilaku Petani dalam Pengembangan Usahatani Karet di Kelurahan Tanjung Batu Kabupaten Ogan lir. Skripsi. Fakultas Pertanian Universits Sriwijaya. Tidak dipublikasikan.

Baroh, I., Selby Hamzah, M., \& Harpowo, H. (2021). Analisis Pemasaran Biji Kopi Robusta di Desa Jambuwer Kecamatan Kromengan Kabupaten Malang . Agriecobis: Journal of Agricultural Socioeconomics and Business, 4(1), 65-74.

Behera, S.S. \& Ray, R.C. (2016). Konjac Glucomannan: A Promising Polysaccharide of Amorphophallus Konjac K. Koch in Health Care. International Journal Biological Macromolecules, 92: 942-56.

Berty, G. \& Mulligan, C. (2016). Competitiveness of Small Farms and Innovative Food Supply Chains: The Role of Food Hubs in Creating Sustainable Regional and Local Food Systems. Sustainability, 8(7): 131

Bidarti, A., Darwanto, D.H., Hartono, S., Jamhari. (2019). Supplier Structure and Performance Evaluation of Supplier Network Phase Rice Supply Chain Management in South Sumatra. Agraris: Journal of Agribusiness and Rural Develpoment Research, 5(1): 7-20.

Dai, J.J., Ding, M.R, Chen, J., \& Qi, J. (2020). Optimization of Gel Mixture Formulation Based on Weighted Value using Response Surface Methodology. Journal of Food, 18(1):500-507.

Dermoredjo, S.K., Azis, M., Saputra, Y. H., Susilowati, G., \& Sayaka, B. (2021). Sustaining Porang (Amorphophallus muelleri Blume) Production for Improving Farmers' Income. Proceeding IOP Conf. Series: Earth and Environmental Science, 648 012032, hlm. 1-10.

Hamzah, Y. I., Ibrahim, J. T., Baroh, I., \& Mufriantie, F. (2020). Analisis Daya Saing Kopi Indonesia di Pasar Internasional. Agriecobis: Journal of Agricultural Socioeconomics and Business, 3(1), 17-21.

Handayani, Y., Simatupang, T.M., \& Perdana, T. (2015). Agri-food Supply Chain Coordination: The State-of-the Art and Recent Developments. Logistics Research, 8(1): 1-15.

Iqbal, M, I,. Sadat, M. A., \& Azisah. (2020). Analisis Saluran dan Marjin Pemasaran Umbi Porang di Kelurahan Balleangin di Kecamatan Balocci Kabupaten Pangkajene dan Kepulauan. Jurnal Agribis, 12(2): 1-12

Kashima, H., Uemoto, S., Eguchi, K., Endo, M. Y., Miura A., Kobayashi T. (2016). Effect of Soy Protein Isolate Preload on Postprandial Glycemic Control in Healthy Humans. Nutrition, 32(9): 965-9

Kumar, A., \& Kushwaha, G.S. (2018). Supply chain management practices and operational performance of fair price shops in India : an empirical study. Logforum: Scientific Journal of Logistics, 14(1): 85-99

Lin, P. C.. \& Wu L. S. (2011). How Supermarket Chains in Taiwan Select Suppliers of Fresh Fruit and Vegetables via Direct Purchasing. The Service Industries Journal, 31(8): 1237-1255.

Lontoh, A. P., Santoso, E., Kurniawati, A., \& Sari, M. (2019). Yield Evaluation of Selected Clones Apomictic lles-lles (Amorphophallus muelleri Blume) on Second Growing Period. Indonesian Journal of Agronomy, 47(2): 171-179.

Maysaroh, M., Irianto, H., \& Adi, R. K. (2018). Supply Chain Management Ubi Kayu (Manihot esculenta) di Agroindustri Tiwul Instan Kabupaten Gunungkidul. Agriecobis: Journal of Agricultural Socioeconomics and Business, 1(2), 45-57.

Nee, A. Y. H. (2008). Supply Chain Model For Rice In Malaysia -Basics And Challenges. ECER Regional Conference 2008, hlm. 1-18

Ncube, D. (2020). The Importance of Contract Farming to Small-scale Farmers in Africa and the Implications for Policy: A Review Scenario. The Open Agriculture Journal, 14: 59-86.

Pasaribu, G., Hastuti, N., Efiyanti, L., \& Waluyo, T. K. (2020). Optimasi Teknik Pemurnian Glukomanan Pada Tepung Porang (Amorphophallus Muelleri Blume). Jurnal Penelitian Hasil Hutan, 37(7): 197-203. 
Patil, K.A., \& Kale, N.R. (2016). A Model for Smart Agriculture Using loT. In 2016 International Conference on Global Trends in Signal Processing, Information Computing and Communic at lon (ICGTSPICC), hm. 543-545

Pradani, W. A., Harisudin, M. \& Khomah, I. (2021) Strategi Pemasaran Bekatul Beras Merah Instan di CV. Pantiboga Natural Food Specialist, Kecamatan Matesih, Kabupaten Karanganyar. Agriecobis: Journal of Agricultural Socioeconomics and Business, 4(1): 46-57.

Perdana, T., Handayani, Y., Sadeli, A. H., Utomo, D.S., \& Hermiatin, F. R. (2020). A Conceptual Model of Smart Supply Chain for Managing Rice Industry, Mimbar Agribisnis, 36(1): 128-138.

Relawati, R., Masyhuri, Lestari R. Waluyati, L. R., \& Mulyo, J. H. (2019). Strategi Pemasaran Apel Malang. Agriecobis: Journal of Agricultural Socioeconomics and Business, 02 (01):32-46

Santoso, D. W. (2015). How to Increase Value Added of Porang (Amorphophallus Oncophyllus) as Forestry Commodity?. Review Integrative Business Economy Research, 4(2): 278-291.

Sharma, S., Giri, S. \& Rai, S. S.(2013). Supply Chain Management of Rice in India: A Rice Processing Company's Perspective. International Journal of Managing Value and Supply Chains, 4(1): 25-36.

Solihin, Setiawan, I., \& Wulandari, E. (2019). Kinerja pusat Pelatihan Perdesaan Swadaya Berbasis Pesantren di Jawa Barat. Mimbar Agribisnis, 5(2): 304-315

Wahyuni, K. I., Rohmah, M. K., Ambari, Y. \& Romadhan, B. K. (2020). Pemanfaatan Umbi Porang (Amorphophallus muelleri BI) Sebagai Bahan Baku Keripik. Jurnal Karinov, 3(1): 1-4.

Wang, S. Q., Huang, G. Q., Du, Y. L., \& Xiao, J. X. (2017). Modification of Konjac Glucomannan by ReducedPressure Radio-Frequency Air Plasma. International Journal of Food Engineering, 13(8): 1-9

Wu, L., Yue, X., Jin, A., \& Yen, D.C. (2016). Smart Supply Chain Management: A Review and Implications for Future Research. The International Journal of Logistics Management, 27: 395-417

Yanuriati, A., \& Basir, D. (2020). Peningkatan Kelarutan Glukomanan Porang (Amorphophallus muelleri Blume) dengan Penggilingan Basah dan Kering, Agritech, 40(3): 223-231.

Yanuriati, A., Marseno, D. W., Rochmadi, R., \& Hermayani, E. (2017). Porang Glucomannan-Xanthan Gel and Its Stability after Chilled and Frozen Storage. Agritech, 37(2): 121-131

Yoshida, A., Kimura, T., Tsunekawa, K., Araki, O., Ushiki, K., Ishigaki, H., Shoho, Y., Suda, I., Hiramoto, S., \& Murakami, M. (2020). Glucomannan Inhibits Rice Gruel-Induced Increases in Plasma Glucose and Insulin Levels. Annals of Nutrition and Metabolism, 76:259-267

Zhang, C., Chen, J-C. Yang, C. Q. (2014). Konjac Glucomannan: A Promising Polysaccharide for OCDDS. Carbohydrate Polymers, 104(1): 175-181.

Zhang, J. C., Luo, J. L. \& Li, J. (2021) Agricultural co-operatives participating in supply chain integration in China: A qualitative comparative analysis. Plant Phenomics and Precion Agriculture, 16(4): 131-161. 